\title{
Mussel biofiltration effects on attached bacteria and unicellular eukaryotes in fish rearing seawater
}

Eleni EV Voudanta, Konstantinos Ar Kormas, Sebastién Monchy, Alice Delegrange, Dorothée Vincent, Savvas Genitsaris, Urania Christaki

Mussel biofiltration is a widely used approach for the mitigation of aquaculture water. In this study, we investigated the effect of mussel biofiltration on the communities of particle-associated bacteria and unicellular eukaryotes in a sea bass aquaculture in southern North Sea. We assessed the planktonic community changes before and after biofiltration based on the diversity of the 16S and 18S rRNA genes by using next generation sequencing technologies. Although there was no overall reduction in the operational taxonomic units (OTU) numbers between the control (no mussels) and the test (with mussels) tanks, a clear reduction in the relative abundance of the top three most dominant OTUs in every sampling time was observed, ranging between 2-28\% and $16-82 \%$ for Bacteria and Eukarya, respectively. The bacterial community was dominated by OTUs related to phytoplankton blooms and/or high concentrations of detritus. Among the eukaryotes, several fungal and parasitic groups were found. Their relative abundance in most cases was also reduced from the control to the test tanks; a similar decreasing pattern was also observed for both major higher taxa and functional (trophic) groups. Overall, this study showed the effectiveness of mussel biofiltration on the decrease of microbiota abundance and diversity in seawater fueling fish farms. 
1 Mussel biofiltration effects on attached bacteria and unicellular eukaryotes in fish rearing

2 seawater

3

4 E. Voudanta ${ }^{1}$, K. A. Kormas ${ }^{2 *}$, S. Monchy ${ }^{1}$, A. Delegrange ${ }^{1}$, D. Vincent ${ }^{1}$, S. Genitsaris ${ }^{1}$, U.

5 Christaki $^{1}$

6

$7 \quad{ }^{1}$ Laboratoire d'Océanologie et Géosciences (LOG), UMR CNRS 8187, Université du Littoral

8 Côte d' Opale (ULCO), 32 av. Foch, 62930 Wimereux, France

9

102 Department of Ichthyology \& Aquatic Environment, School of Agricultural Sciences,

11 University of Thessaly, 38446 Volos, Greece

12

13 * Corresponding author; Tel.: +30-242-109-3082, Fax: +30-242-109-3157, E-mail:

14 kkormas@uth.gr

15

16 Running title: Biofiltration of bacteria and protists 


\section{ABSTRACT}

Mussel biofiltration is a widely used approach for the mitigation of aquaculture water. In

20 this study, we investigated the effect of mussel biofiltration on the communities of particle-

21 associated bacteria and unicellular eukaryotes in a sea bass aquaculture in southern North Sea.

22 We assessed the planktonic community changes before and after biofiltration based on the

23 diversity of the 16S and 18S rRNA genes by using next generation sequencing technologies.

24 Although there was no overall reduction in the operational taxonomic units (OTU) numbers

25 between the control (no mussels) and the test (with mussels) tanks, a clear reduction in the 26 relative abundance of the top three most dominant OTUs in every sampling time was observed,

27 ranging between $2-28 \%$ and $16-82 \%$ for Bacteria and Eukarya, respectively. The bacterial

28 community was dominated by OTUs related to phytoplankton blooms and/or high concentrations

29 of detritus. Among the eukaryotes, several fungal and parasitic groups were found. Their relative

30 abundance in most cases was also reduced from the control to the test tanks; a similar decreasing

31 pattern was also observed for both major higher taxa and functional (trophic) groups. Overall,

32 this study showed the effectiveness of mussel biofiltration on the decrease of microbiota

33 abundance and diversity in seawater fueling fish farms. 
35

36

37

38

39

40

41

42

43

44

45

46

47

48

49

50

51

52

54

55

56

57

\section{INTRODUCTION}

Water column contains a mixture of microscopic particles of various sizes from colloidal non-living material to living microorganisms ranging from viruses, free-living and attached prokaryotes and unicellular eukaryotes (Azam \& Malfatti 2007). Mussels are efficient nonselective filter-feeders. They can filter large volumes of seawater and retain a wide size range of particles (ca. 5 - $35 \mu \mathrm{m}$ diameter) such as uneaten feed, phytoplankton and bacteria (Soto \& Mena 1999, Neori et al. 2004). The large biofiltration capacity of suspended mussels has provided rationale for their use in integrated multi-trophic aquaculture (IMTA) systems as an eco-friendly mitigation tool of excess amount of particulate matter (Petersen et al. 2004). In fact, they have been used to control the abundance of pelagic primary producers (Dolmer 2000), to filter small particles of salmon fish feed and feces (Reid et al. 2010, Irisarri et al. 2015), and to reduce the environmental impact caused by organic wastes in marine fish farming (Lehtinen et al. 1998, Gao et al. 2008) and therefore appear as efficient biomarkers of environmental contamination to assess marine environments quality (Boening 1999, Brenner et al. 2014). The important role of mussels is also depicted by their use in aquatic polyculture, where salmonid farming and mussel longlines; this method provides an economical and environmental resolution that both reduces organic pollution and enhances shellfish production (Lehtinen et al. 1998; Gao et al. 2008).

3 Bacteria can be found in the marine environment either as free-living $(<10 \mu \mathrm{m})$ or particle associated, i.e. attached bacteria $(>10 \mu \mathrm{m})$ which are often larger and in higher local concentrations than their free-living counterparts (Caron et al. 1982, Acinas et al. 1999). Attached bacteria contribution to the total bacteria activity is highly variable and depends on both the abundance of attached bacteria and their associated suspended particles concentrations. 
58 Apart from bacteria, unicellular eukaryotes constitute the other major biological component of

59 plankton, including a wide array of cell morphologies/sizes and biological traits, which renders

60 this taxonomical group differentially susceptible to mussel filtration.

61 European sea bass (Dicentrarchus labrax L. 1758, Moronidae, Perciformes) is one of the

62 most cultured marine fish representing a great economic importance for industrial seafood

63 production (FAO 2014). The health of reared fish is highly susceptible to microbiological risk

64 imposed by bacteria, unicellular eukaryotes including fungi and parasites, as well as viruses that

65 can trigger significant losses in aquaculture production. Additionally, environmental problems

66 induced by coastal eutrophication can have direct (e.g. harmful algal blooms, fish parasites) and

67 indirect (e.g. water hypoxia/anoxia) effects that might reduce the quality of ecosystem services,

68 including aquaculture, fisheries and recreation (Rekker et al. 2015). Nowadays, among the top

69 ranked scientific questions for social scientists are related to aquaculture effects (Rudd 2014),

70 such as the disposal of particulate and dissolved wastes resulting from aquaculture installations

71 and activities.

72

As the microbiological risk for sea bass aquaculture might rise from microorganisms with

73 a wide range of cell morphology, physiology, ecology and biology, and bearing in mind that

74 mussels are not selective feeders in terms of microorganisms but rather on size (e.g. Delegrange

75 et al. 2015), the mitigation effect of mussels biofiltration is not expected to be equally efficient

76 for all the, directly or indirectly, undesired microorganisms in waters associated with

77 aquaculture. In a recent study, Delegrange et al. (2015) evaluated the effect of mussel filtration to

78 dampen the phytoplankton bloom and enhance juvenile sea bass physiological performances.

79 During the same experiment, we focused on structural changes of the particle-associated bacteria

80 and unicellular eukaryotic communities. We specifically evaluated whether mussel biofiltration 
81 effectively reduces the overall microbial species richness, also considering the more under-

82 studied eukaryotic communities, as determined by next generation sequencing technologies.

83

84 MATERIALS AND METHODS

Experimental set-up and sampling. The possibility to use mussels as a mitigation tool

to prevent phytoplankton spring bloom noxious effects on farmed fish was tested during a 35-day

test-case mesocosm experiment in a fish farm in the north of France during the spring

phytoplankton bloom (16/04 -21/05/2013). The experimental setting has been described in

detail in Delegrange et al. (2015) and consisted of three $5 \mathrm{~m}^{3}$ mesocosms. The experimental

system was supplied with bulk seawater, i.e. natural coastal North Sea water mixed with

seawater released from the Gravelines Power Plant cooling system (France) heated $+10{ }^{\circ} \mathrm{C}$

compared to in situ temperature and chlorinated (1\%). Bulk seawater was filtered by blue

mussels (Mytillus edulis) in a biofiltration tank (M) before fueling a test tank (T) containing

juvenile sea bass (Dicentrachus labrax). The third tank was used as a control (C), and contained

juvenile sea bass reared in bulk seawater (i.e. not biofiltered). In all the tanks, the flow rate was

set at $5 \mathrm{~m}^{3} \mathrm{~h}^{-1}$ allowing for one turnover every hour, and photoperiod followed natural day:night

cycle. Due to logistic constraints of the aquaculture facilities (e.g. number of available tanks,

tanks volume, amount of mussels and fish needed and subsequent risk of contamination) a single

experiment was carried out. However, from the number of complementary parameters monitored

(see next section) and the number of repeated measures over time, observed tendencies and

patterns were clearly illustrating mussels' biofiltration impact on microbiota. Mussel filtration 
104 seawater turnover in the T tank, box plot of effective clearance rates based on both chlorophyll $a$ 105 (chl-a) and total phytoplankton abundance were drawn.

106 Temperature, salinity, $\mathrm{pH}$, dissolved oxygen, turbidity, chl-a were measured twice a week 107 while phytoplankton taxonomy in $\mathrm{C}$ and $\mathrm{T}$ tanks was investigated at days (d) $0,3,10,17,24,31$, 10835 and are reported elsewhere (Delegrange et al. 2015). In this study, sampling took place at 109 days $\mathrm{d} 0, \mathrm{~d} 7, \mathrm{~d} 14, \mathrm{~d} 21, \mathrm{~d} 28$ and $\mathrm{d} 35$. Water samples $(500-1000 \mathrm{ml})$ collected in $\mathrm{C}$ and $\mathrm{T}$ tanks 110 were screened with a $200 \mu \mathrm{m}$ mesh to retain larger particles and most metazoans. Samples were 111 then filtered on $3 \mu \mathrm{m}$ nucleopore filters (47 $\mathrm{mm}$ diameter) using a low filtration pressure in order 112 to minimize organism disruption. The filters were immediately frozen in liquid nitrogen and 113 stored at $-80^{\circ} \mathrm{C}$ until analysis.

114 Molecular analysis and data processing. Bulk DNA of the retained material on the 115 filters, was extracted and purified, after filtration, with the PowerWater ${ }^{\circledR}$ DNA isolation kit 116 (Mobio Laboratories Inc, CA, USA), following the manufacturer's protocol. The quantity of the 117 DNA was between 0.78 and $10.5 \mathrm{ng} \mu \mathrm{L}^{-1}$ as measured by the Qubit ${ }^{\circledR} 2.0$ Fluorometer (Thermo 118 Fisher Scientific Inc, Massachusetts, USA).

119 The DNA samples were amplified using the two universal eukaryote primers $18 \mathrm{~S}-82 \mathrm{~F}$

120 (5'-ACCAGACTTGCCCTCC-3') (Lopez-Garcia et al. 2003) and Euk-516r (5'-

121 ACCAGACTTGCCCTCC-3') (Amann et al. 1990), and two universal bacterial primer S-D-

122 Bact-0341-b-S-17 (CCTACGGNGGCWGCAG) and S-D-Bact-0785-a-A-21

123 (GACTACHVGGGTATCTAATCC) (Klindworth et al. 2014). The eukaryote primers amplify a 124 domain around $490 \mathrm{bp}$ of the V2-V3 $18 \mathrm{~S}$ rDNA regions, while the prokaryote primers amplify a 125465 bp domain from the V3-V4 16S rRDNA regions rDNA. The libraries were constructed by 126 'Genes Diffusion' company (Lille, France). Firstly, Polymerase Chain Reaction (PCR) were 
127 carried out, using the two sets of universal primers, according to standard conditions for

128 Platinum Taq High-Fidelity DNA Polymerase (Invitrogen, Carlsbad, CA, USA), with 5 ng of

129 environmental DNA as template, using the GeneAmp PCR System Apparatus (Applied

130 Biosystems, Foster City, CA, USA). The PCR cycle conditions were the following: after the

131 denaturation step at $95{ }^{\circ} \mathrm{C}$ for $5 \mathrm{~min}, 30$ cycles of amplification were performed at $95{ }^{\circ} \mathrm{C}$ for $30 \mathrm{~s}$,

$13250{ }^{\circ} \mathrm{C}$ for $30 \mathrm{~s}$, and $72{ }^{\circ} \mathrm{C}$ for $1 \mathrm{~min}$. A final extension step of $7 \mathrm{~min}$ at $72{ }^{\circ} \mathrm{C}$ was included. A

133 second PCR was carried out on each sample independently, in order to add a 10 bp (base pairs)

134 specific tag sequence to each sample. Finally, all the amplicons were mixed together

135 stoichiometrically before their sequencing in one run of MiSeq PE 2x300 Illumina (CNRS-

136 UMR8199, Lille).

137 The sequences were processed using the MOTHUR v1.34.0 software (Schloss et al.

138 2009) following the standard operating procedure (Schloss et al. 2011). Only reads above $492 \mathrm{bp}$

139 for eukaryotes and 465 bp for bacteria, with homopolymers shorter than 8 bp were kept in the

140 analysis. Eukaryotes and Bacteria sequences were dereplicated to the unique sequences and

141 aligned independently against the SILVA 108 database (Pruesse et al. 2007) containing only the

142 targeted region (V2-V3 for eukaryotes and V3-V4 for bacteria) and matching the universal

143 primers used in this study. Subsequently, around 130 sequences for eukaryotes and 8.956

144 sequences for bacteria suspected of being chimeras were removed using the UCHIME software

145 (Edgar 2010). The remaining sequences were clustered into operational taxonomical units

146 (OTUs) at 97\% similarity. Single singletons (sequences present only once in one sample) were

147 removed from downstream analysis. Finally, the dataset containing both eukaryote and bacterial

148 sequences was normalized according to the lowest number of reads in a sample (55,102 reads).

149 Rarefaction curves calculated for all the sampling dates approached a plateau in most cases when 
$150 \geq 97 \%$ levels of sequence similarities were applied (Fig. S1). Sequencing data from this study

151 have been submitted to the Sequence Read Archive (SRA) (http://www.ncbi.nlm.nih.gov/sra)

152 with accession number SRP061259.

153 Taxonomic classification was assigned using BLASTN (Altschul et al. 1990), against the

154 sequences (PR2 database containing 23.003 protist sequences (Guillou et al. 2013) for

155 eukaryotes and against Silva database for Bacteria containing 530.946 bacterial sequences

156 (Pruesse et al. 2007). The OTUs identified as metazoans (69 OTUs) were removed from 157 analysis.

158 For each date, OTU relative abundances between the $\mathrm{C}$ and $\mathrm{T}$ tanks were compared with 159 the Wilcoxon test. For the whole experiment Chi2 test was used to compare $\mathrm{C}$ and $\mathrm{T}$ tanks for 160 OTU abundance frequency distributions of eukaryotes taxonomic and trophic groups. Statistical 161 analyses were done using the PAST 3c software (Hammer et al. 2001).

162

163

RESULTS

164

Environmental parameters. The hydrological parameters were reported in detail in

165 Delegrange et al. (2015). Temperature, salinity and dissolved oxygen, were similar, while

166 turbidity and chl-a were significantly higher in the C-tank (Wilcoxon-Mann-Whitney test,

$167 \mathrm{p}<0.001$; Delegrange et al. 2015). Chl-a - which is a proxy for phytoplankton biomass - ranged

168 between $0.80 \mu \mathrm{g} \mathrm{L}^{-1}$ and $10.35 \mu \mathrm{g} \mathrm{L}^{-1}$ (mean $\left.\pm \mathrm{sd}, 4.97 \pm 3.80 \mu \mathrm{g} \mathrm{L}-1\right)$ in the C-tank, whereas it

169 ranged between 0.19 and $2.28 \mu \mathrm{g} \mathrm{L}^{-1}$ (mean $\left.\pm \mathrm{sd}, 0.79 \pm 0.62 \mu \mathrm{g} \mathrm{L}-1\right)$ in the T-tank (Tab. S1,

170 Delegrange et al. 2015).

171 Filtration effect. Mussel effective clearance rates based on chl-a concentration removal

172 and phytoplankton abundance decrease reached 11 to 76 and 26 to $60 \mathrm{~m}^{3}$ per day, respectively, 
173 being at least twice as much as seawater turnover in T tank (Fig. 1). This impacted OTUs relative

174 abundances and changes in the total number of OTUs between $\mathrm{C}$ and $\mathrm{T}$ tanks were different for

175 Bacteria and Eukarya at the various sampling points (Tab. 1). The lower bacterial OTU richness

176 in the $\mathrm{T}$ tank compared to the $\mathrm{C}$ tank, was observed at $\mathrm{d} 0, \mathrm{~d} 14$ and $\mathrm{d} 28$, while for the Eukarya

177 less OTUs in the $\mathrm{T}$ tank were observed at $\mathrm{d} 0, \mathrm{~d} 7, \mathrm{~d} 21$, and $\mathrm{d} 35$. For the Bacteria, the percentage

178 of shared OTUs (Fig. 2) between C and T tanks ranged only between 8.3\% (21 d) and 12.9\% (28

179 d). For the Eukarya this value was twice higher ranging between $15.5 \%$ (d28) and $38.7 \%$ (d7).

180 Although the contribution of rare, common and abundant OTUs (Fig. S2) was similar for

181 both Bacteria and Eukarya at all sampling points, a decrease in the relative abundance of the top

182 three most abundant OTUs was recorded (Fig. 3). The only cases where an increase occurred

183 from the control to the test tank was only for Eukarya on d0 and a much less important increase

184 on $\mathrm{d}$, for the three most dominant OTUs. In all the rest cases, there was no increase to the extent

185 that an OTU dominated (Fig. 3). The relative abundance of the single most dominant Bacteria

186 OTU varied between $4.6 \%$ and $19.3 \%$ (Tab. 1). The dominant Bacteria in the $\mathrm{C}$ tank were related

187 to Polaribacter spp. (d7, d14, d28), Sulfitobacter sp. (d0), Pseudoalteromonas sp. (d21) and

188 Arcobacter sp. (d35) (Fig. 3). The relative abundance of the single most abundant Eukarya OTU

189 in the C tank ranged between $15.5 \%$ and $96.1 \%$ (Tab. 1) and these were related to Phaeocystis

190 sp. (d0, d7, d21, d28), an unaffiliated Dinophyceae (d14) and Zoothamnium sp. (d35) (Fig. 2).

191 On d7 was the only case where the cumulative relative abundance of the top three most dominant

192 OTU slightly increased from C to T tank (Fig. 3). Regarding Eukarya, mussel biofiltration

193 resulted in decreased OTUs richness in the T tank for all higher level taxa in all trophic groups

194 (Fig. 4) however these higher values did not result to any significant difference of the mean

195 ranks (Wilcoxon test, $\mathrm{p}>0.05$ ). However, considering all the sampling dates there were 
196 significant differences regarding the frequency distribution of the OTUs abundance between the 197 two tanks, except for Rhizaria and Excavata (Chi2 test, Fig. 4).

199 included the 15,046 bacterial OTUs were found in both tanks during the experiment.

200 Bacteroidetes alone included $82.1 \%$ of total OTUs $(12,347)$, and these OTUs were dominated by 201 members of the Flavobacteriaceae family (73.24\% of total OTUs number; 11,021) (Fig. S3).

202 From the rest of the bacterial phyla, the $\gamma$ - and $\alpha$-Proteobacteria dominated by including $7.2 \%$ $203(1,084)$ and 3.9\% (593) of the total number of OTUs, respectively (Fig. S2). OTUs were sorted 204 into major trophic groups, such as microplankton grazers, autotrophs, picoplankton grazers, 205 nanoplankton grazers, mixotrophs and parasites.

206 The 968 eukaryotic OTUs were affiliated into nine 'super-groups' and 41 higher 207 'taxonomic groups' distributed in all samples (Fig. S4). Alveolates were the most diverse group 208 accounting for $34.4 \%$ of the total OTUs (333 OTUs), followed by Stramenopiles (30.4\%, 294

209 OTUs) and Opisthokonta (17.9\%, 173 OTUs). Within, these three supergoups, the most 210 representative 'taxonomic groups' in terms of OTU numbers were Ciliata, Labyrithulea, and 211 Fungi. The other six supergroups included from 6 to 52 OTUs. The relative OTU abundance of 212 Stramenopiles was relatively stable in all samples (32.6 $\pm 3 \%)$. Fungi OTUs were well 213 represented in all samples $(10.6 \pm 4.2 \%)$ except in the $\mathrm{C}$ tank at $\mathrm{d} 28$ where they were absent. 214 Relative abundance of Alveolata-related OTUs was between 28.6 and 50\% and showed highest 215 values in the $\mathrm{C}$ tank at $\mathrm{d} 14$ and $\mathrm{d} 28$ (50 and $41.3 \%$, respectively). The most dominant eukaryotic 216 OTUs (Fig. 3) were related to Phaeocystis sp., Gyrodinium spp., Zoothamnium sp. and some 217 unaffiliated dinoflagellates, bicosidia and ciliates. Finally, a significant positive correlation was 218 observed between the total number of OTUs and the number of parasitic OTUs (Fig. 5; p<0.01). 


\section{DISCUSSION}

221 Mussels filtration efficiency to remove suspended particles including microorganisms

222 (Dame \& Dankers 1988, Asmus \& Asmus 1991) renders the use of these organisms an eco-

223 friendly way to improve water quality in fish farming areas by dampening organic particulate

224 matter concentrations (Burkholder \& Shumway 2011). Delegrange et al. (2015) and Fig. 1

225 demonstrated the mussel clearance rates to be at least twice the water inflow, resulting in

226 effective phytoplankton bloom dampening although inducing a probable food shortage for

227 mussels. This was congruent with the low mussel condition index $\left(3.43 \pm 0.45 \mathrm{mg} \mathrm{cm}^{-3}\right)$

228 measured in the same experiment (Delegrange et al. 2015) and could also be related to the

229 reproductive cycle of the mussels in the North Sea (Riisgård et al. 2001). In this study, mussel

230 filtration impact was considered regarding changes in species richness and relative abundance of

231 planktonic unicellular eukaryotes and particle-attached bacteria. However, our dataset and

232 experimental design did not allow assessing whether these modifications resulted from partial or

233 total digestion by mussels.

234 Although, absolute numbers of one species can remain the same and still show a decrease

235 in relative abundance if other species increase (making absolute numbers of organisms more

236 important in the context of infection or toxicological potential), in the present study only the

237 relative abundance of OTUs was taken into consideration. This was because of biases of deep-

238 sequencing, which involve pyrosequencing errors and copy-number variations among taxa

239 (Kunin et al. 2010; Medinger et al. 2010), that can produce non-realistic abundance values (see

240 Genitsaris et al. 2016). We assessed OTUs diversity by using Illumina sequencing of the $18 \mathrm{~S}$ and 
241 16S rRNA genes on $\geq 3 \mu \mathrm{m}$ material. The resulting rarefaction curves indicated that for most of

242 the samples, the majority of the existing species richness was revealed (Fig. S1).

243 Filtration effect. As expected due to the highly dynamic nature of the tanks, i.e. water

244 renewal time and mussel filtration, the bacterial and eukaryotic OTUs showed a great variability

245 with no clear pattern from one sampling to the other (Fig. 2). However, the different effect of

246 mussel filtration was clearly illustrated on bacterial and eukaryotic communities for the richness

247 and the relative abundance of the most dominant OTUs, as these are most likely to persist in the

248 tanks compared to the rest of the OTUs with much lower abundances. The low degree of the

249 bacterial community structure overlap between the control and test tanks $(8.3-12.9 \%$ of shared

250 OTUs) agrees well with the general notion that ca. 10\% of shared bacterial fingerprints occurs

251 between ecologically different or distant habitats (Zinger et al. 2011). This suggests that the two

252 tanks harbor different communities, probably due to mussel filtration. Filtration impact was also

253 shown for higher size spectra $(>10 \mu \mathrm{m})$, particularly on phytoplankton components (Delegrange

254 et al. 2015). Overall, different bacterial OTUs appeared at each sampling point, possibly due to

255 the fact that various bacterial species occur in particle dominated environments (Simon et al.

256 2014) such as the one we investigated. Moreover, there were no major differences in the relative

257 abundance of rare, common and abundant bacterial and eukaryotic OTUs (Fig. S2). This could

258 point to the misleading conclusion that mussel filtration has no important effect on these

259 microorganisms. Zooming in, however, to the dominant bacterial OTUs, a different view comes

260 up. These dominant OTUs are most likely to represent fundamental species in the fish tanks, or

261 at least represent the most well adapted (sensu Konopka 2009) species to the prevailing

262 conditions of the tanks. At all sampling times, when considering the three most abundant OTUs, 
263 the decrease for the bacterial and the eukaryotic OTUs was $2-28 \%$ and $16-72 \%$, respectively

264 (Fig. 3) implying their important role in the plankton community.

265 For the eukaryotic community, the mussel filtration effect was different. A much higher

266 and more variable percentage of shared OTUs between control and test tanks $(15.5-38.7 \%)$ was

267 observed, compared to the attached bacteria. This is probably due to the lower species richness

268 of eukaryotes. Interestingly, while the number of OTUs found in the test tank was in most cases

269 lower than in the control tanks this difference was not significant regarding relative abundance

270 (Wilcoxon test). However, the results of the Chi2 test clearly showed that the frequency

271 distribution of the eukaryotic OTUs resulted from two statistically distinct populations.

272 A plausible hypothesis is that the differences of the filtration effect can be linked to

273 different traits of the eukaryotic groups, such as the much larger heterogeneity in cell size,

274 morphology, life cycle, metabolic/trophic status (Fenchel 1988). For this reason, we focused on

275 specific groups, at different taxonomic and trophic/functional levels (Fig. 4).

276 The frequency distribution of OTUs was significantly different (Chi 2 test, Fig. 4)

277 between the two tanks indicating that each tank can be considered as a different 'ecosystem'. In a

278 parallel study, Delegrange et al. (2015) showed that mussel filtration significantly reduced the

279 phytoplankton biomass 10 times, shifting towards less deleterious phytoplankton species and

280 reduced water column turbidity 4 times. Here, we elucidated that such changes also take place

281 for other eukaryotes and attached bacteria.

282 Bacteria. Not surprisingly, many of the taxonomic groups found (Fig. S3) were related to

283 microorganisms attached either on particles or other surfaces. This is enforced by the dominant

284 OTUs at every sampling time in both tanks, as well as by the presence of the overall dominant

285 group, the Flavobacteriaceae (Fig. S3), which are well known to be associated with particles in 
286 the marine environment (Simon et al. 2014). Polaribacter spp. and Sulfitobacter sp. were among

287 the most abundant and frequently occurring OTUs in most of the samples along with

288 Pseudoalteromonas (Tab. 1, Fig. 3). The concomitant occurrence of these three species is not

289 surprising since they are among the most important ones during phytoplankton bloom as reported

290 by Choi et al. (2015) in an Antarctic polynya. Recently, a Sulfitobacter species was isolated from

291 the toxic marine diatom Pseudo-nitzschia multiseries (Hong et al. 2015). P. multiseries was not

292 present during the experiment nor during the year-round survey carried out in the fish farm but

293 P. delicatissima and P. pungens were identified (Delegrange et al. 2015). Whether Sulfitobacter

294 holds a similar relationship with these two Pseudo-nitzschia species, as with P. multiseries,

295 remains to be investigated. Moreover, it has also been shown that Sulfitobacter promotes diatom

296 cell division, particularly in coastal environments (Amin et al. 2015), enforcing, thus, its close

297 association with the diatoms in the tanks. Sulfitobacter has been found to be among the first

298 colonisers of sediment trap collected particles after a phytoplankton bloom (Lecleir et al. 2014)

299 and it is also related to diatom and Phaeocystis bloom termination (as is the case in the tanks we

300 investigated) but even in marine diatom cultures (Schäfer et al. 2002). These clues explain the

301 dominance but also the active association of Sulfitobacter with the marine algal material of the

302 tanks.

303 Polaribacter is well known to thrive in the North Sea phytoplankton blooms (Xing et al.

304 2015). It is considered to have a vital role in the decomposition of sulfated polysaccharides

305 (Gómez-Pereira et al. 2012) such as the ones found in phytoplankton cell walls, most likely

306 including Phaeocystis globosa (Murray et al. 2007, Wemheuer et al. 2015) and other algal

307 organic material (Williams et al. 2013, Klindworth et al. 2014). In an Antarctic polynya,

308 Delmont et al. (2014) observed Polaribacter dominance at the end of a Phaeocystis antarctica 
309 bloom, just as we did after the $P$. globosa bloom. The close association of Polaribacter with

310 non-Phaeocystis blooms has also been shown for North Sea diatom blooms (Teeling et al. 2012,

311 Klindworth et al. 2014) and reinforces its dominant role in the mussel tanks. Finally,

312 Polaribacter sp. is one of the major members of the Pseudo-nitzschia associated microbiota and

313 it is known to enhance domoic acid production by Pseudo-nitzschia australis (Sison-Mangus et

314 al. 2014). Thus, the observed abundance reduction of this OTU through the mussel filtration

315 could reduce the relevant risk, as Pseudo-nitzschia has been found to occur in the investigated

316 tanks (Delegrange et al. 2015). The observed reduction of Polaribacter abundance by mussel

317 filtration could be an additional factor to account for in future biofiltration studies.

Pseudolateromonas sp. was also among the dominant bacterial OTUs. This

319 microorganism has been associated with diatoms (Amin et al. 2012) but it has been assigned a

320 potential algicidal role (Lee et al. 2000). In our study, it peaked after the diatom bloom (d24),

321 implying its latter role in the tanks.

322

At the end of the experiment (d35), the dominant bacterium was related to Arcobacter sp.

323 This genus is not frequently occurring in marine plankton as it is usually related to animal

324 pathogens (Vandamme et al. 2005) or faecal material (Maugeri et al. 2004, Ottaviani et al. 2013).

325 The bacterial family that most commonly cause diseases in reared sea bass stocks is represented

326 by Vibrionaceae. The major disease-causing species of this family are Vibrio anguillarum and

327 Photobacterium damselae subsp. piscicida, Vibrio rotiferianus and Vibrio harveyi (Toranzo et al.

328 2005, Austin 2012). However, other species can affect sea bass such as the Piscirickettsia

329 salmonis, (McCarthy et al. 2005), Aeromonas veronii (Uzun \& Ogut, 2015), Pseudoalteromonas

330 spp. (Pujalte et al. 2007). In our data set, some of the above mentioned genera were found (data

331 not shown), however, they were always falling in the rare group ( $<1 \%$ relative abundance). 
Eukarya. Plankton can also cause harmful effects to both wild (e.g Thangaraja et al.

333 2007, Tang \& Gobler 2009) and farmed fish (Bruno et al. 1989, Treasurer et al. 2003). The

334 negative effects of phytoplabkton can be: (1) the production of a non-toxic high biomass (mucus

335 overproduction) - bloom forming, leading to foams or scum, which can deplete oxygen levels

336 inducing fish mortality; (2) the production of potent toxins (e.g. domoic acid by diatoms); and

337 (3) the cause of damage in farmed fish gills, mechanically induced by stress exposure or through

338 the production of haemolytic substances (Sellner et al. 2003). In our study, the unicellular

339 eukaryotic communities were dominated by Phaeocystis sp. The haptophyte P. globosa is the

340 central, recurring species in the phytoplankton bloom in the investigation area (e.g. Stelfox-

341 Widdicombe et al. 2004, Hernandez-Fariñas et al. 2014) and was also dominant in the

342 experimental tanks (Delegrange et al. 2015) although it was demonstrated not to impact fish

343 physiological performances (Amara et al. 2013). Among the most abundant eukaryotes,

344 Dinoflagellates relative abundance was reduced by mussel biofiltration (Fig. 3). These organisms

345 are considered major diatom grazers in the plankton community (Grattepanche et al. 2011a, b)

346 and are therefore trophically linked to the diatoms in the tanks.

347 The ecological role of ciliates lies on their grazing on small sized phytoplankton but also

348 on their free-living vs. symbiotic, commensal or parasitic but never mutualistic life mode (Lynn

349 2010). Among the dominant OTUs, the relative abundance of Aspidisca sp. and Euplotes sp.

350 were found to be reduced by mussels filtration. These two surface-associated ciliates are frequent

351 and abundant in marine snow (Artolozaga et al. 1997), estuaries (Mironova et al. 2012), while

352 they also occur as lagoon and wastewater treatment plants epiphytes (Martin-Cereceda et al.

353 1996, Dhib et al. 2013), as well as biofouling microorganisms (Watson et al. 2015). Their high

354 abundance is probably related to the high turbidity levels in the tanks (Delegrange et al. 2015), 
355 providing multiple niches to proliferate. The observed turbidity decrease (Delegrange et al. 2015)

356 coincided with the reduction of their relative abundance (Fig. 3).

357 In this study we observed a positive correlation between OTUs number and parasitic

358 OTUs (Fig. 5). This parasites pool contains endosymbionts of other protists but also parasites of

359 special interest for the aquaculture field, i.e. fungi and ichthyosporeans. However, the

360 survivability of fish parasites in the plankton requires further research. Such parasites could be

361 protozoa, myxosporea, helminths and parasitic crustaceans. They may become causative agents

362 of diseases leading to pathologies and mortality, triggering a decrease of fitness and growth and

363 modifying fish behaviour (Feist \& Longshaw, 2008). Several parasites belong to unicellular

364 eukarya. These include Amoebozoa, Apicomplexa, Ciliata, Chlorophyceae, and Euglenophyceae,

365 which have been identified as important pathogens for sea bass. Therefore, their potential as

366 serious skin and gill parasites should be assessed (Alvarez-Pellitero et al. 1993, Sterud 2002).

367 The role of such parasites is increasing as new information comes along. For example, some

368 protozoan cysts are now considered to act synergistically with bacterial pathogens (Lambrecht et

369 al. 2015). In our study, on day 35 , Zoothamnium sp. was the dominant eukaryotic OTU in the

370 control tank, which, however, was drastically reduced through mussel biofiltration. Although this

371 epibiont ciliate has not been found as a parasite of farmed sea bass it is a well-known parasite of

372 copepods (Burris \& Dam 2014), white shrimp (Vidal-Martinez et al. 2002) and freshwater carps

373 (Dash et al. 2015).

374 Other potential parasites, but not being amongst the dominant OTUs, belonged to the

375 groups of MALV, Labyrinthulomycetes, Pirsonia, Oomyeta, Apicomplexa, Perkinsea, Fungi, and

376 Cercozoa (Fig. S4). Members of the MALV group are enigmatic marine alveolate groups and are

377 most likely considered as intracellular symbionts or parasites (e.g reviewed in Skovgaard 2014). 
378 In a recent succession study in the eastern English Channel, Fungi and Cercozoa, were mostly

379 found to co-occur with polysaccharide producing Bacillariophyceae (Christaki et al. 2014).

380 Fungi are possibly related to the polysaccharide degradation of the freshly produced organic

381 material by primary producers (Kimura \& Naganuma 2001). It is known for diatoms that

382 polysaccharides are their main exudates (Myklestad 1995 and references therein), and these

383 sugars could promote the growth of Fungi. Many Cercozoa are parasites of marine organisms,

384 including large heavily silicified diatoms (e.g. Tillmann et al. 1999), which could explain why

385 Fungi and Cercozoa are detected in bloom situations and are poorly represented in oligotrophic

386 conditions (Georges et al. 2014). Labyrinthulomycetes, which appeared at the end of the

387 experiment, are common osmo-heterotrophic marine protists (López-García et al. 2001) having

388 parasitic, commensalistic, or mutualistic relationships with their hosts. Their presence is

389 congruent with their role in decomposition processes (Collado-Mercado et al. 2010) by

390 colonizing fecal pellets, including under deep-sea conditions (Raghukumar et al. 2004).

391 Mussel biofiltration is becoming a widely used eco-friendly water purification process in

392 aquaculture. This study is an additional contribution to integrated aquaculture focusing on the

393 effect of mussel biofiltration on individual OTUs of particle-associated bacteria and protists. The

394 decrease of both prokaryotic and eukaryotic OTUs abundance and diversity indicated that mussel

395 biofiltration affects their community structure. The bacterial community was dominated by

396 species closely associated to detritus and/or phytoplankton bloom derived material. The

397 eukaryotic community contained a large number of potential parasites of fish and planktonic

398 microorganisms, whose accurate role in the trophodynamics of planktonic system and their risk

399 on aquaculture requires further research. 


\section{ACKNOWLEDGEMENTS}

402 www.englisheditor.webs.com is thanked for its English proofing. We are thankful to the

403 reviewers for their helpful comments that significantly improved the original manuscript.

404

405 REFERENCES

406 Acinas SG, Antón J, Rodríguez-Valera F (1999) Diversity of free-living and attached bacteria in 407 offshore western Mediterranean waters as depicted by analysis of genes encoding 16S

408 rRNA. Appl Environ Microbiol 65:514-522

409

Altschul SF, Gish W, Miller W, Myers EW, Lipman DJ (1990) Basic local alignment search tool. J Mol Biol 215:403-410

411

412

413

414

415

416

417

418

419

420

421

422

423

Alvarez-Pellitero P, Sitja-Bobadilla A, Franco-Sierra A (1993) Protozoan parasites of wild and cultured sea bass, Dicentrarchus labrax (L.), from the Mediterranean area. Aquacult Fisher Managem 24:101-108

Amann RI, Binder BJ, Olson RJ, Chisholm SW, Devereux R, Stahl DA (1990) Combination of 16S rRNA-targeted oligonucleotide probes with flow cytometry for analyzing mixed microbial populations. Appl Environ Microbiol 56:1919-1925

Amara R, Filipuci I, Vincent D, Goulard F, Breton E (2013) Do transparent exopolymeric particles (TEP) derived from Phaeocystis globosa bloom impact the physiological performances of European sea bass juveniles. Aquaculture 414-415:149-154

Amin SA, Hmelo LR, van Tol HM, Durham BP, Carlson LT, Heal KR, Morales RL, Berthiaume CT, Parker MS, Djunaedi B, Ingalls AE, Parsek MR, Moran MA, Armbrust EV (2015) Interaction and signalling between a cosmopolitan phytoplankton and associated bacteria. Nature 522:98-101 
424 Amin SA, Parker MS, Armbrust EV (2012) Interactions between diatoms and bacteria.

$425 \quad$ Microbiol Mol Biol R 76:667-684

426 Artolozaga I, Santamaría E, López A, Ayo B, Iriberri J (1997) Succession of bacterivorous

427 protists on laboratory-made marine snow. J Plankton R 19:1429-1440

428 Asmus RM, Asmus H (1991) Mussel beds: limiting or promoting phytoplankton? J Exp Mar 429 Biol Ecol 148:215-232

430

Austin B (ed) (2012) Infectious disease in aquaculture: Prevention and control, Woodhead Publishing, Sawston

432 Azam F, Malfatti F (2007) Microbial structuring of marine ecosystems. Nat Rev Microbiol 5:782-791

434 435

436

437

438

439

440

441

442

443

444

445

446 Caron DA, Davis PG, Madin LP, Sieburth McN J (1982) Heterotrophic bacteria and 
448 Choi SB, Kim JG, Jung MY, Kim SJ, Min UG, Si OJ, Park SJ, Yeon Hwang C, Park J, Lee SH, Rhee SK (2015) Cultivation and biochemical characterization of heterotrophic bacteria associated with phytoplankton bloom in the Amundsen sea polynya, Antarctica. DeepSea Res II. DOI: 10.1016/j.dsr2.2015.04.027

452 Christaki U, Kormas K, Genitsaris S, Georges C, Sime-Ngando Tl, Viscogliosi E, Monchy S (2014) Winter-summer succession of unicellular eukaryotes in a meso-eutrophic coastal system. Microb Ecol 67:13-23

455 Collado-Mercado E, Radway J, Collier J (2010) Novel uncultivated labyrinthulomycetes revealed by $18 \mathrm{~s}$ rDNA sequences from seawater and sediment samples. Aquat Microb Ecol 58:215 228

Dame RF, Dankers N (1988) Uptake and release of materials by a Wadden sea mussel bed. J Exp Mar Biol Ecol 118:207-216

Dash G, Majumder D, Raghu Ramudu K (2015) Seasonal distribution of parasites in freshwater

462

463

464

465

466

467

468

469 exotic carps of West Bengal, India. Indian J Anim Res 49:95-102

Delegrange A, Vincent D, Duret M, Amara R (2015) The use of mussels for mitigating the noxious effect of phytoplankton spring blooms on farmed fish. Aquacult Eng 66:52-61

Delmont TO, Hammar KM, Ducklow HW, Yager PL, Post AF (2014) Phaeocystis antarctica blooms strongly influence bacterial community structures in the Amundsen Sea polynya. Front Microbiol 5, 646

Dhib A, Brahim MB, Ziadi B, Akrout F, Turki S, Aleya L (2013) Factors driving the seasonal distribution of planktonic and epiphytic ciliates in a eutrophicated Mediterranean Lagoon. Mar Pollut Bull 74:383-395 
470 Dolmer P (2000) Feeding activity of mussels Mytilus edulis related to near-bed currents and

471 phytoplankton biomass. J Sea Res 44:221-231

472 Edgar R (2010) Search and clustering orders of magnitude faster than BLAST. Bioinformatics

$473 \quad 26: 2460-2461$

474 FAO (2014) The state of world fisheries and aquaculture. Food and Agriculture Organization of 475 the United Nations, Rome.

476 Feist SW, Longshaw M (2008) Histopathology of fish parasite infections - Importance for 477 populations. J Fish Biol 73:2143-2160

478 Fenchel T (1988) Marine plankton food chains. Annu Rev Ecol Syst 19:19-38

479 Gao QF, Xu WZ, Liu XS, Cheung SG, Shin PKS (2008) Seasonal changes in C, N and P 480 budgets of green-lipped mussels Perna viridis and removal of nutrients from fish 481 farming in Hong Kong. Mar Ecol-Prog Ser 353:137-146

482 Genitsaris S, Monchy S, Denonfoux J, Ferreira S, Kormas KAr, Sime-Ngando T, Viscogliosi E, 483 Christaki U (2016) Marine microbial community structure assessed from combined 484 metagenomic analysis and ribosomal amplicon deep-sequencing. Mar Biol Res 12:30-42

485 Georges C, Monchy S, Genitsaris S, Christaki U (2014) Protist community composition during 486 early phytoplankton blooms in the naturally iron-fertilized Kerguelen area (Southern 487 Ocean). Biogeosciences 11:5847-5863

488 Gómez-Pereira PR, Schüler M, Fuchs BM, Bennke C, Teeling H, Waldmann J, Richter M, 489 Barbe V, Bataille E, Glöckner FO, Amann R (2012) Genomic content of uncultured 490 Bacteroidetes from contrasting oceanic provinces in the North Atlantic Ocean. Environ $491 \quad$ Microbiol 14:52-66

492 Grattepanche JD, Breton E, Brylinski JM, Lecuyer E, Christaki U (2011a) Succession of 
493

494

495

496

497

498

499

500

501

502

503

504

505

506

507

508

509

510

511

512

513

514

515

primary producers and micrograzers in a coastal ecosystem dominated by Phaeocystis globosa blooms. J Plankton Res 33:37-50

Grattepanche JD, Vincent D, Breton E, Christaki U (2011b) Microzooplankton herbivory during the diatom-Phaeocystis spring succession in the eastern English Channel. J Exp Mar Biol Ecol 404:87-97

Guillou L, Bachar D, Audic Sp, Bass D, Berney Cd, Bittner L, Boutte C, Burgaud Gt, de Vargas C, Decelle J, del Campo J, Dolan JR, Dunthorn M, Edvardsen B, Holzmann M, Kooistra WHCF, Lara E, Le Bescot N, Logares R, Mahé Fdr, Massana R, Montresor M, Morard R, Not F, Pawlowski J, Probert I, Sauvadet A-L, Siano R, Stoeck T, Vaulot D, Zimmermann P, Christen R (2013) The Protist Ribosomal Reference database (PR2): a catalog of unicellular eukaryote Small Sub-Unit rRNA sequences with curated taxonomy. Nucleic Acids Res 41:D597-D604

Hammer Ø, Harper D, Ryan P (2001) PAST: Paleontological statistics software package for education and data analysis. Palaeontol Electr 4:9

Hernández-Fariñas T, Soudant D, Barillé L, Belin C, Lefebvre A, Bacher C (2014) Temporal changes in the phytoplankton community along the French coast of the eastern English Channel and the southern bight of the North Sea. ICES J Mar Sci 71:821-833

Hong Z, Lai Q, Luo Q, Jiang S, Zhu R, Liang J, Gao Y (2015) Sulfitobacter pseudonitzschiae sp. nov., isolated from the toxic marine diatom Pseudo-nitzschia multiseries. Int J Syst Evol Micr 65:95-100

Irisarri J, Fernández-Reiriz MJ, Labarta U, Cranford PJ, Robinson SMC (2015) Availability and utilization of waste fish feed by mussels Mytilus edulis in a commercial integrated multitrophic aquaculture (IMTA) system: A multi-indicator assessment approach. Ecol Indic 
517 Kimura H, Naganuma T (2001) Thraustochytrids: A neglected agent of the marine microbial 518 food chain. Aquat Ecosyst Health 4:13-18

519 Klindworth A, Mann AJ, Huang S, Wichels A, Quast C, Waldmann J, Teeling H, Glöckner FO (2014) Diversity and activity of marine bacterioplankton during a diatom bloom in the North Sea assessed by total RNA and pyrotag sequencing. Mar Genom 18:185-192

Konopka A (2009) What is microbial community ecology? ISME J 3:1223-1230

523 Kunin V, Engelbrektron A, Ochman H, Hugenholtz P (2010) Wrinkles in the rare biosphere:

524 Pyrosequencing errors can lead to artificial inflation of diversity estimates. Environ $525 \quad$ Microbiol 12:118-123

526 Lambrecht E, Baré J, Chavatte N, Bert W, Sabbe K, Houf K (2015) Protozoan cysts act as a 527 survival niche and protective shelter for foodborne pathogenic bacteria. Appl Environ

$528 \quad$ Microbiol 81:5604-5612

529 Lecleir GR, Debruyn JM, Maas EW, Boyd PW, Wilhelm SW (2014) Temporal changes in 530 particle-associated microbial communities after interception by nonlethal sediment traps.

$531 \quad$ FEMS Microbiol Ecol 87:153-163

532 Lee S-O, Kato J, Takiguchi N, Kuroda A, Ikeda T, Mitsutani A, Ohtake H (2000) Involvement

533 of an extracellular protease in algicidal activity of the marine bacterium

$534 \quad$ Pseudoalteromonas sp. strain A28. Appl Environ Microbiol 66:4334-4339

535 Lehtinen KJ, Mattsson K, Tana J, Grotell C, Engström C (1998) Effects on ecosystem structure 536 and function of fish farming as simulated in littoral brackish water mesocosms.

$537 \quad$ Aquaculture 165:179-202

538 López-García P, Philippe H, Gail F, Moreira D (2003) Autochthonous eukaryotic diversity in 

Natl Acad Sci USA 100:697-702

541 López-García P, Rodríguez-Valera F, Pedrós-Alió C, Moreira D (2001) Unexpected diversity of small eukaryotes in deep-sea Antarctic plankton. Nature 409:603-607

543 Lynn DH, 2010. The ciliated protozoa: Characterization, classification and guide to the $544 \quad$ literature, 3rd edn, Springer

545 Martín-Cereceda M, Serrano S, Guinea A (1996) A comparative study of ciliated protozoa 546 communities in activated-sludge plants. FEMS Microbiol Ecol21:267-276

547 Maugeri TL, Carbone M, Fera MT, Irrera GP, Gugliandolo C (2004) Distribution of potentially 548 pathogenic bacteria as free living and plankton associated in a marine coastal zone. J $549 \quad$ Appl Microbiol 97:354-361

550 McCarthy Ú, Steiropoulos NA, Thompson KD, Adams A, Ellis AE, Ferguson HW (2005) $551 \quad$ Confirmation of Piscirickettsia salmonis as a pathogen in European sea bass 552 Dicentrarchus labrax and phylogenetic comparison with salmonid strains. Dis Aquat $553 \quad$ Organ 64:107-119

554 Medinger R, Nolte V, Pandey RV, Jost S, Ottenwalder B, Schlotterer C, Boenigk J (2010) 555 Diversity in a hidden world: potential and limitation of next-generation sequencing for 556 surveys of molecular diversity of eukaryotic microorganisms. Mol Ecol 19(suppl 1):32$557 \quad 40$

558 Mironova E, Telesh I, Skarlato S (2012) Diversity and seasonality in structure of ciliate 559 communities in the Neva Estuary (Baltic Sea). J Plankton Res 34:208-220

560 Murray A, Arnosti C, De La Rocha C, Grossart H, Passow U (2007) Microbial dynamics in 561 autotrophic and heterotrophic seawater mesocosms. II. Bacterioplankton community 
563 Myklestad SM (1995) Release of extracellular products by phytoplankton with special emphasis 564 on polysaccharides. Sci Total Environ 165:155-164

565 Neori A, Chopin T, Troell M, Buschmann AH, Kraemer GP, Halling C, Shpigel M, Yarish C 566 (2004) Integrated aquaculture: Rationale, evolution and state of the art emphasizing seaweed biofiltration in modern mariculture. Aquaculture 231:361-391

568 Ottaviani D, Chierichetti S, Rocchegiani E, Bartolini C, Masini L, Santarelli S, Leoni F (2013) Bioaccumulation experiments in mussels contaminated with the food-borne pathogen

570 Arcobacter butzleri: Preliminary data for risk assessment. BioMed Res Int Article ID

571 1534419

572 Petersen JK, Bougrier S, Smaal AC, Garen P, Robert S, Larsen JEN, Brummelhuis E (2004) 573 Intercalibration of mussel Mytilus edulis clearance rate measurements. Mar Ecol Prog

574 Ser 267:187-194

575 Pruesse E, Quast C, Knittel K, Fuchs B, Ludwig W, Peplies J, Glöckner F (2007) SILVA: a

576

577 comprehensive online resource for quality checked and aligned ribosomal RNA sequence data compatible with ARB. Nucleic Acids Res 35:7188-7196

579

580

Pujalte MJ, Sitjà-Bobadilla A, Macián MC, Álvarez-Pellitero P, Garay E (2007) Occurrence and virulence of Pseudoalteromonas spp. in cultured gilthead sea bream (Sparus aurata L.) and European sea bass (Dicentrarchus labrax L.). Molecular and phenotypic characterisation of $P$. undina strain U58. Aquaculture 271:47-53

582 Raghukumar C, Raghukumar S, Sheelu G, Gupta SM, Nagender Nath B, Rao BR (2004) Buried 583 in time: Culturable fungi in a deep-sea sediment core from the Chagos Trench, Indian $584 \quad$ Ocean. Deep-Sea Res I 51:1759-1768 
585 Reid GK, Liutkus M, Bennett A, Robinson SMC, MacDonald B, Page F (2010) Absorption

586

587

588

589

590

591

592

593

594

595

596

597

598

599

600

601

602

603

604

605

606

607

efficiency of blue mussels (Mytilus edulis and M. trossulus) feeding on Atlantic salmon (Salmo salar) feed and fecal particulates: Implications for integrated multi-trophic aquaculture. Aquaculture 299:165-169

Rekker J, de Carvlaho Belchior C, Royo Gelabert E (eds) (2015) State of Europe's seas. European Environment Agency Report No 2/2015

Riisgård HU (2001) On measurement of filtration rates in bivalves: the stony road to reliable data: review and interpretation. Mar Ecol Prog Ser 211:275-291.

Riisgård HU, Larsen PS, Pleissner D (2014) Allometric equations for maximum filtration rate in blue mussel Mytilus edulis and importance of condition index. Helgol Mar Res 68:193198.

Rudd MA (2014) Scientists' perspectives on global ocean research priorities. Front Mar Sci 1, 36

Schäfer H, Abbas B, Witte H, Muyzer G (2002) Genetic diversity of 'satellite' bacteria present in cultures of marine diatoms. FEMS Microbiol Ecol 42:25-35

Schloss PD, Gevers D, Westcott SL (2011) Reducing the effects of PCR amplification and sequencing artifacts on 16S rRNA-based studies. PLoS ONE 6:e27310

Schloss PD, Westcott SL, Ryabin T, Hall JRand others (2009) Introducing mothur: Opensource, platform-independent, community-supported software for describing and comparing microbial communities. Appl Environ Microbiol 75:7537-7541

Sellner KG, Doucette GJ, Kirkpatrick GJ (2003) Harmful algal blooms: Causes, impacts and detection. J Ind Microbiol Biot 30:383-406

Simon HM, Smith MW, Herfort L (2014) Metagenomic insights into particles and their associated microbiota in a coastal margin ecosystem. Front Microbiol 5,466 
608 Sison-Mangus MP, Jiang S, Tran KN, Kudela RM (2014) Host-specific adaptation governs the

609 interaction of the marine diatom, Pseudo-nitzschia and their microbiota. ISME J 8:63-76

610 Skovgaard A (2014) Dirty tricks in the plankton: Diversity and role of marine parasitic protists. Acta Protozool 53:51-62

612 Soto D, Mena G (1999) Filter feeding by the freshwater mussel, Diplodon chilensis, as a biocontrol of salmon farming eutrophication. Aquaculture 171:65-81

614 Stelfox-Widdicombe CE, Archer SD, Burkill PH, Stefels J (2004) Microzooplankton grazing in 615 Phaeocystis and diatom-dominated waters in the southern north sea in spring. J Sea Res

616 $51: 37-51$

617 Sterud E (2002) Parasites of wild sea bass Dicentrarchus labrax from Norway. Dis Aquat Organ 618 48:209-212

Tang YZ, Gobler CJ (2009) Characterization of the toxicity of Cochlodinium polykrikoides isolates from Northeast US estuaries to finfish and shellfish. Harmful Algae 8:454-462

621

622

Teeling H, Fuchs BM, Becher D, Klockow C, Gardebrecht A, Bennke CM, Kassabgy M, Huang

623

S, Mann AJ, Waldmann J, Weber M, Klindworth A, Otto A, Lange J, Bernhardt J, Reinsch C, Hecker M, Peplies J, Bockelmann FD, Callies U, Gerdts G, Wichels A,

624 Wiltshire KH, Glöckner FO, Schweder T, Amann R (2012) Substrate-controlled 625

626 succession of marine bacterioplankton populations induced by a phytoplankton bloom. Science 336:608-611

628

Thangaraja M, Al-Aisry A, Al-Kharusi L (2007) Harmful algal blooms and their impacts in the middle and outer ROPME sea area. Int J Oceans Oceanogr 2:85-98

629 Tillmann U, Hesse KJ, Tillmann A (1999) Large-scale parasitic infection of diatoms in the $630 \quad$ Northfrisian Wadden Sea. J Sea Res 42:255-261 
631 Toranzo AE, Magariños B, Romalde JL (2005) A review of the main bacterial fish diseases in

632 mariculture systems. Aquaculture 246:37-61

633 Treasurer JW, Hannah F, Cox D (2003) Impact of a phytoplankton bloom on mortalities and

634 feeding response of farmed Atlantic salmon, Salmo salar, in west Scotland. Aquaculture

$635 \quad 218: 103-113$

636 Uzun E, Ogut H (2015) The isolation frequency of bacterial pathogens from sea bass

637 (Dicentrarchus labrax) in the Southeastern Black Sea. Aquaculture 437:30-37

638 Vandamme P, Dewhirst FE, Paster BJ, On SLW (2005) Genus II. Arcobacter. In: Brenner DJ,

639 Krieg NR, Staley JT (eds) Bergey's manual of systematic bacteriology. Second edition.

640 Volume Two. The Proteobacteria. Part C. The Alpha-, Beta-, Delta- and

641 Epsilonproteobacteria. Springer, New York, p 1161-1165

642 Vidal-Martínez VM, Jiménez-Cueto AM, Simá-Álvarez R (2002) Parasites and symbionts of

643 native and cultured shrimps from Yucatán, Mexico. J Aquat Anim Health 14:57-64

644 Watson M, Scardino A, Zalizniak L, Shimeta J (2015) Colonisation and succession of marine

645 biofilm-dwelling ciliates in response to environmental variation. Aquat Microb Ecol

$646 \quad 74: 95-105$

647 Wemheuer B, Wemheuer F, Hollensteiner J, Meyer F-D, Voget S, Daniel R (2015) The green

648 impact: Bacterioplankton response towards a phytoplankton spring bloom in the southern

649 north sea assessed by comparative metagenomic and metatranscriptomic approaches.

$650 \quad$ Front Microbiol 6, 805

651 Williams TJ, Wilkins D, Long E, Evans F, Demaere MZ, Raftery MJ, Cavicchioli R (2013) The

652 role of planktonic Flavobacteria in processing algal organic matter in coastal East

653 Antarctica revealed using metagenomics and metaproteomics. Environ Microbiol 
654 $15: 1302-1317$

655 Xing P, Hahnke RL, Unfried F, Markert S, Huang S, Barbeyron T, Harder J, Becher D, 656 Schweder T, Glöckner FO, Amann RI, Teeling H (2015) Niches of two polysaccharide657 degrading Polaribacter isolates from the North Sea during a spring diatom bloom. ISME 658 J 9:1410-1422

659 Zinger L, Amaral-Zettler LA, Fuhrman JA, Horner-Devine MC, Huse SM, Welch DBM, 660 Martiny JBH, Sogin M, Boetius A, Ramette A (2011) Global patterns of bacterial beta-

661 diversity in seafloor and seawater ecosystems. PLoS ONE 6:e24570

662 
663 Table 1. Qualitative and quantitative normalized richness and abundance of the bacterial (B)

664 and eukaryotic (E) operational taxonomic units (OTUs) in the control (C) and mussels

665 tank (T) at all sampling days (d0-35).

\begin{tabular}{|c|c|c|c|c|c|c|c|}
\hline \multirow[t]{2}{*}{ Sampling } & \multirow[t]{2}{*}{ Reads } & \multicolumn{2}{|c|}{ OTUs } & \multicolumn{2}{|c|}{$\begin{array}{c}\text { Dominance (\%) of the most abundant OTUs } \\
\text { (most closest relative) }\end{array}$} & \multicolumn{2}{|c|}{$\begin{array}{c}\text { No. of the most } \\
\text { dominant OTUs } \\
\text { (cumulative relative } \\
\text { dominance } \geq \mathbf{6 6 . 0} \% \text { ) }\end{array}$} \\
\hline & & B & $\mathbf{E}$ & B & $\mathbf{E}$ & B & $\mathbf{E}$ \\
\hline $\mathrm{Cd} 0$ & 54147 & 1442 & 410 & $\begin{array}{c}9.2 \% \\
\text { (Sulfitobacter sp.) }\end{array}$ & $\begin{array}{c}56.1 \% \\
\text { (Phaeocystis sp.) }\end{array}$ & $\begin{array}{c}46 \\
(66.1 \%)\end{array}$ & $\begin{array}{c}2 \\
(69.3 \%)\end{array}$ \\
\hline $\mathrm{Td} 0$ & 53902 & 1345 & 279 & $\begin{array}{c}9.7 \% \\
\left(\text { Flavobacteriales }^{1}\right)\end{array}$ & $\begin{array}{c}73.2 \% \\
\left(\text { Syndiniales }^{2}\right)\end{array}$ & $\begin{array}{c}41 \\
(66.6 \%)\end{array}$ & $\begin{array}{c}1 \\
(73.2 \%)\end{array}$ \\
\hline $\mathrm{Cd} 7$ & 54950 & 1882 & 189 & $\begin{array}{c}6.1 \% \\
\text { (Polaribacter sp.) }\end{array}$ & $\begin{array}{c}94.9 \% \\
\text { (Phaeocystis sp.) }\end{array}$ & $\begin{array}{c}46 \\
(66.4 \%)\end{array}$ & $\begin{array}{c}1 \\
(94.9 \%)\end{array}$ \\
\hline $\mathrm{Cd} 14$ & 55047 & 2814 & 72 & $\begin{array}{c}4.6 \% \\
\text { (Polaribacter sp.) }\end{array}$ & $\begin{array}{c}29.4 \% \\
\text { (Phaeocystis sp.) }\end{array}$ & $\begin{array}{c}81 \\
(66.1 \%)\end{array}$ & $\begin{array}{c}3 \\
(79.4 \%)\end{array}$ \\
\hline Td14 & 54488 & 1487 & 118 & $\begin{array}{c}8.7 \% \\
\text { (Photobacterium sp.) }\end{array}$ & $\begin{array}{c}22.9 \% \\
\text { (Phaeocystis sp.) }\end{array}$ & $\begin{array}{c}25 \\
(66.2 \%)\end{array}$ & $\begin{array}{c}8 \\
(66.0 \%)\end{array}$ \\
\hline $\mathrm{Cd} 21$ & 54760 & 1310 & 192 & $\begin{array}{c}13.0 \% \\
\text { (Pseudoalteromonas sp.) }\end{array}$ & $\begin{array}{c}15.5 \% \\
\text { (Phaeocystis sp.) }\end{array}$ & $\begin{array}{c}17 \\
(66.6 \%)\end{array}$ & $\begin{array}{c}10 \\
(66.0 \%)\end{array}$ \\
\hline $\mathrm{Td} 28$ & 54661 & 2185 & 208 & $\begin{array}{c}7.4 \% \\
\text { (Pseudoalteromonas sp.) }\end{array}$ & $\begin{array}{c}23.3 \% \\
\text { (Syndiniales) }\end{array}$ & $\begin{array}{c}57 \\
(66.1 \%)\end{array}$ & $6(67.1 \%)$ \\
\hline $\mathrm{Cd} 35$ & 51188 & 1129 & 403 & $\begin{array}{c}16.0 \% \\
\text { (Arcobacter sp.) }\end{array}$ & $\begin{array}{c}16.9 \% \\
\text { (Zoothamnium sp.) }\end{array}$ & $\begin{array}{c}30 \\
(66.0 \%)\end{array}$ & $\begin{array}{c}10 \\
(66.2 \%)\end{array}$ \\
\hline $\mathrm{Td} 35$ & 54160 & 2452 & 222 & $\begin{array}{c}19.3 \% \\
\text { (Pseudoalteromonas sp.) }\end{array}$ & $\begin{array}{c}16.2 \% \\
\text { (Colpodella sp.) }\end{array}$ & $\begin{array}{c}64 \\
(66.0 \%)\end{array}$ & $\begin{array}{c}10 \\
(66.2 \%)\end{array}$ \\
\hline
\end{tabular}

$666{ }^{1}$ NS9 Marine Group

667 2Dinoflagellate Group I Clade 1-X 
668

669

670

671

672 Filtration Rate (WCRpop) calculated from Riisgård et al. (2014) using mussel mean wet weight

673 (modified from Delegrange et al. 2015). 
674
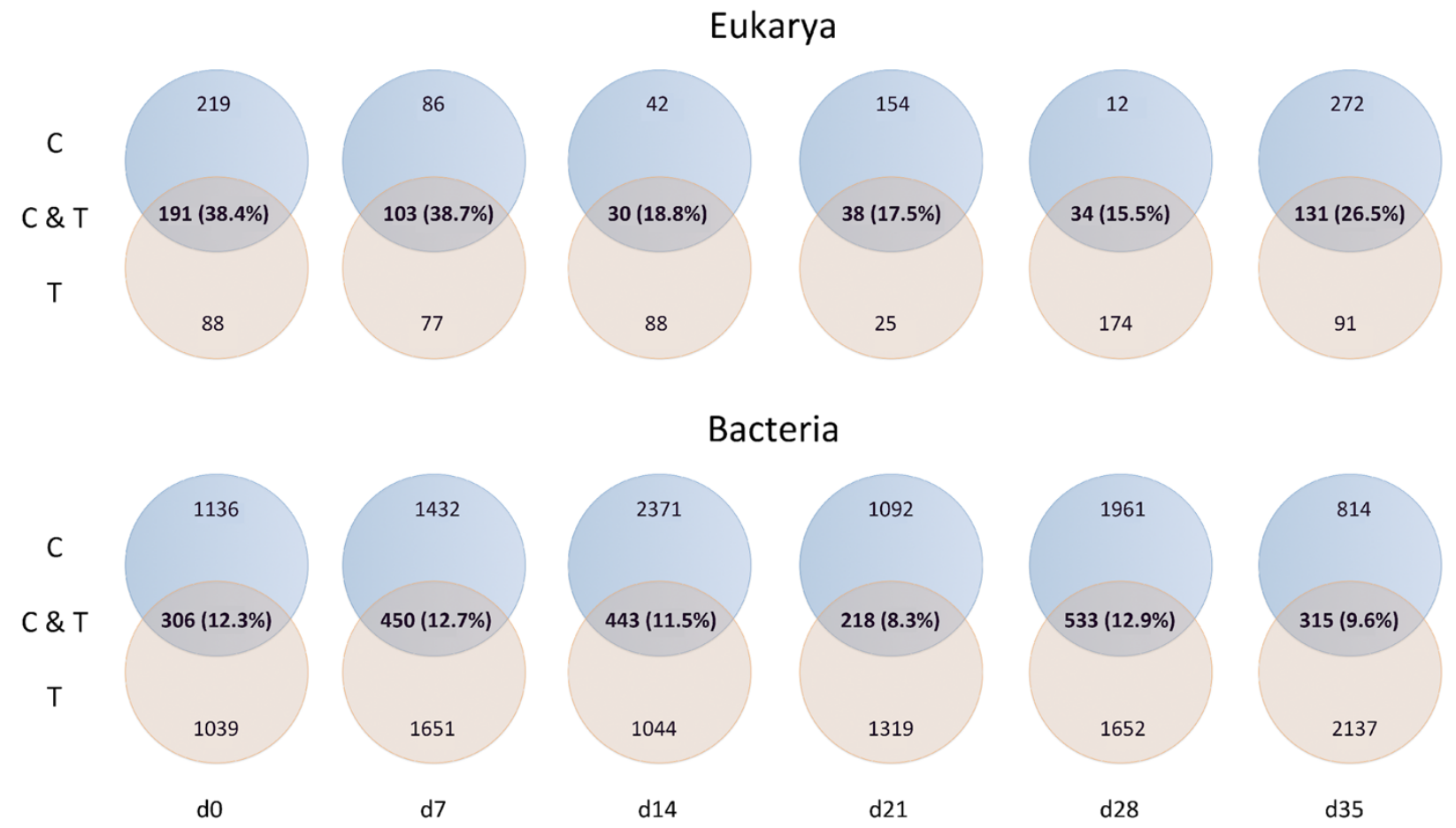

675

676

Figure 2. Number of shared and unique operational taxonomic units in control (C) and mussels'

$677 \operatorname{tank}(\mathrm{T})$. 


\section{Eukarya}

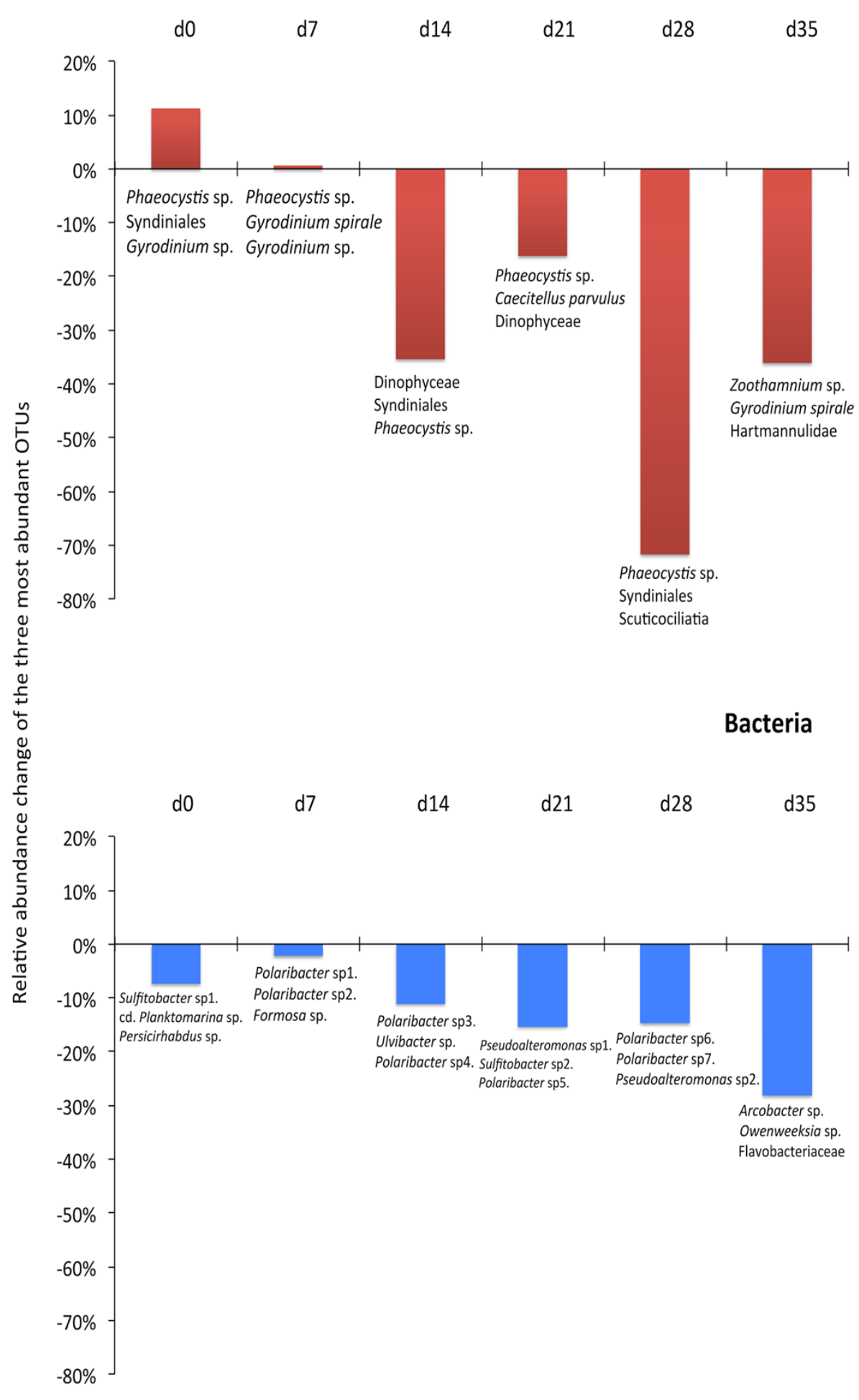

Figure 3. Changes in the relative abundance of the three most abundant operational taxonomic

680 units (OTUs) from the control to test tank in every sampling point. 


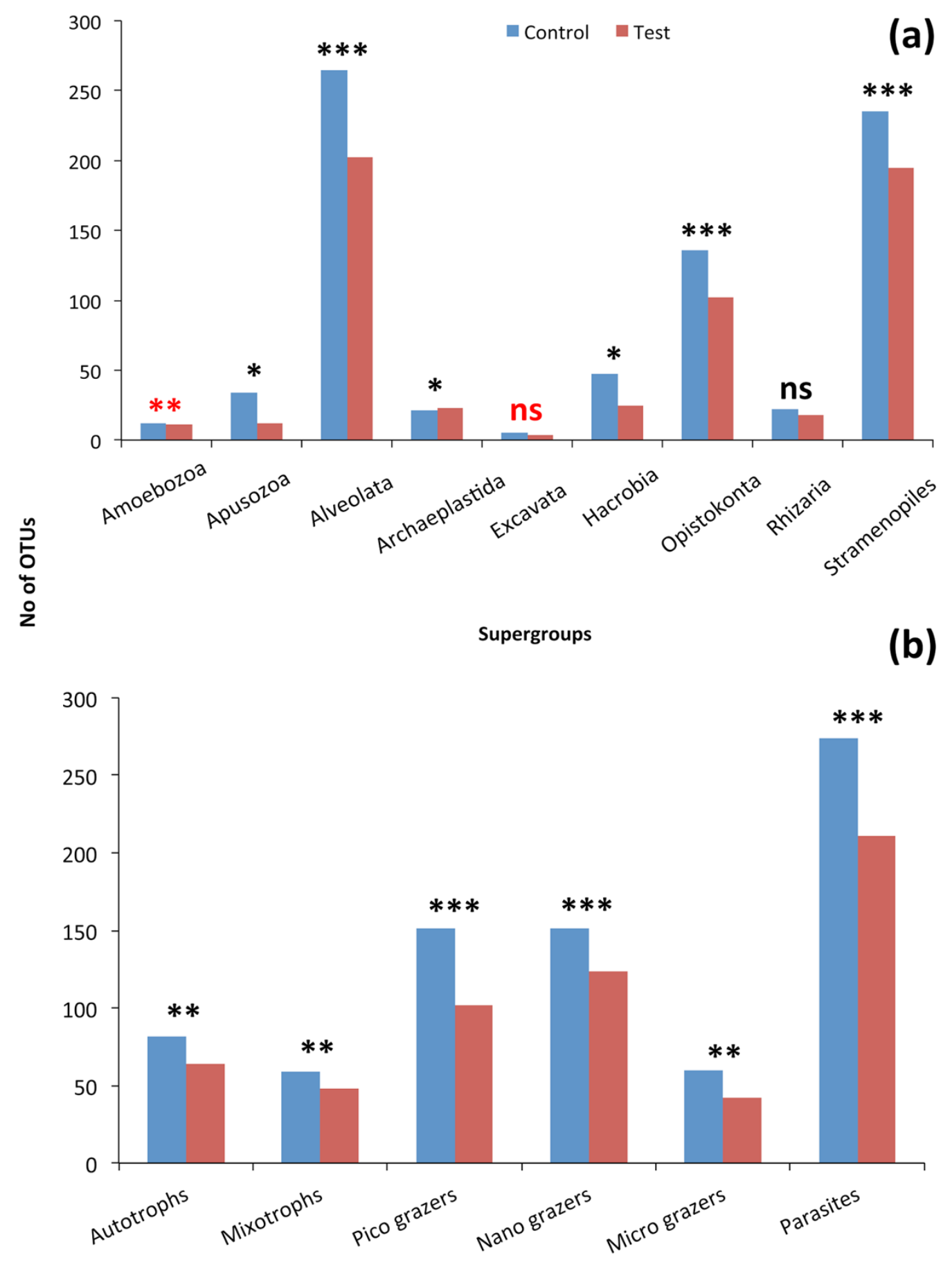

Figure 4. (a) Mean OTU abundance for the 9 super-groups for Control and Test tanks. Chi2 test:

$683 * \mathrm{p}<0.05, * * \mathrm{p}<0.001 * * * \mathrm{p}<0.0001$, red colour: Fisher test when the conditions of Chi2 were not 684 respected (here when $>20 \%$ frequencies were 0 or 1); (b) Mean OTU abundance for 6 trophic 685 groups for Control and Test tanks. Chi2 test: ** $\mathrm{p}<0.001 * * * \mathrm{p}<0.0001$. 


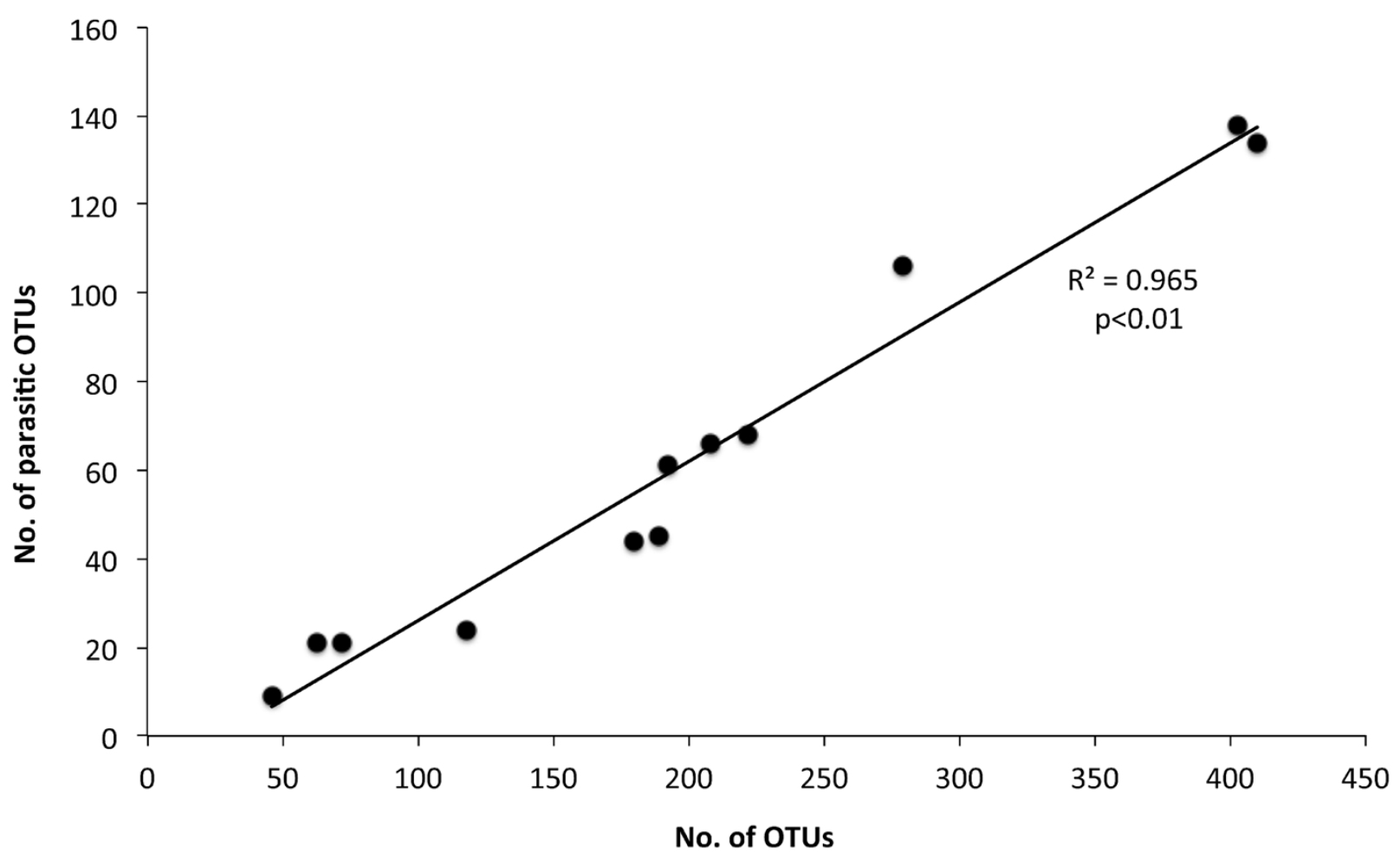

686

Figure 5. Relationship between the number of total eukaryotic and parasitic operational

688 taxonomic units (OTUs) in the control and test tanks in every sampling point. The determination 689 coefficient $\mathrm{R}^{2}$ and the $\mathrm{p}$ value of the regression are also indicated. 